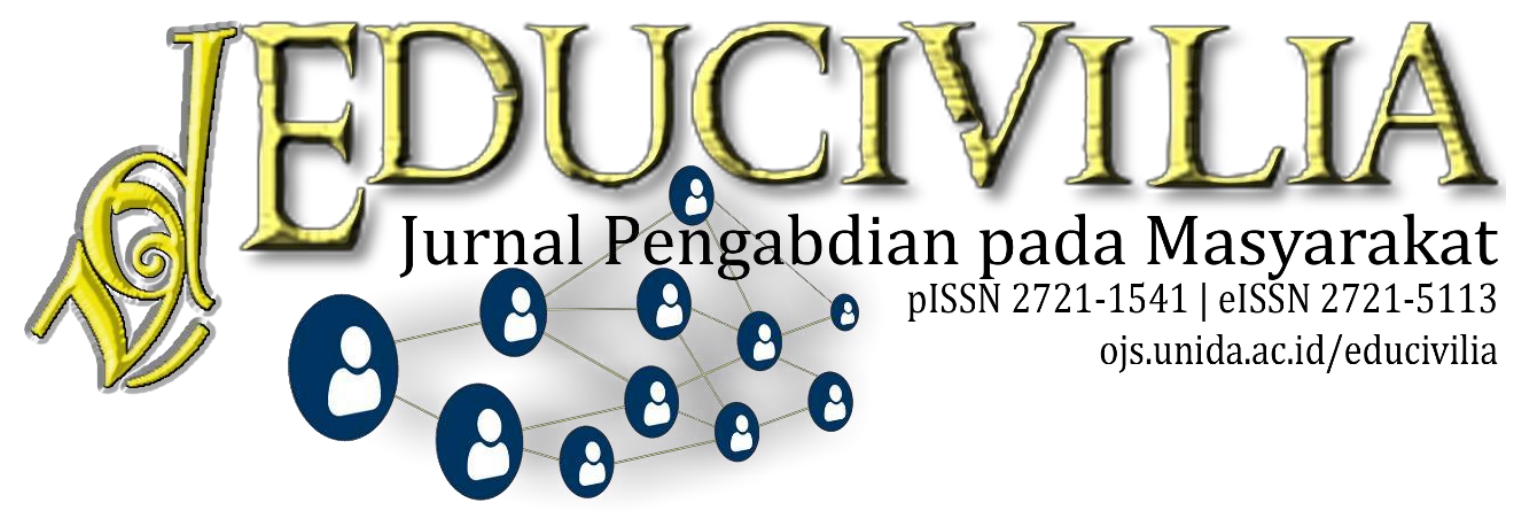

\title{
Penumbuhan Karakter Berbasis Tauhid Melalui Impian Di Desa Tajur
}

\author{
Hasan Bisri1, Fachrur Razi Amir², Sri Wahyuni Ulfah ${ }^{3}$ \\ 1Program Studi Manajemen Pendidikan Islam, Fakultas Keguruan dan Ilmu Pendidikan, \\ Universitas Djuanda Bogor; Jl. Tol Ciawi No. 1 Kotak Pos 35 Bogor 16720 \\ 2Program Studi Pendidikan Bahasa Arab, Fakultas Keguruan dan Ilmu Pendidikan, \\ Universitas Djuanda Bogor; Jl. Tol Ciawi No. 1 Kotak Pos 35 Bogor 16720 \\ 3 Program Studi Pendidikan Guru Sekolah Dasar, Fakultas Keguruan dan Ilmu Pendidikan, \\ Universitas Djuanda Bogor; Jl. Tol Ciawi No. 1 Kotak Pos 35 Bogor 16720
}

Kilas Artikel

Volume 2 Nomor 1

Januari 2021: 1-18

DOI:

10.30997/ejpm.v2i1.2989

Article History

Submission: 29-06-2020

Revised: 09--07-2020

Accepted: 16-07-2020

Published: 25-01-2021

\section{Kata Kunci:}

Penumbuhan Karakter,

Program Teras Impian,

Tauhid

Keywords:

Character development,

Teras Impian Program,

Tauhid

Korespondensi: (Hasan

Bisri)

(hasan.bisri@unida.ac.id)

\begin{abstract}
Abstrak
Program penumbuhan karakter berbasis tauhid melalui 'Teras Impian' di Desa Tajur dilatarbelakangi oleh kondisi masyarakat Kampung Parung Ponteng yang kurang memperhatikan pendidikan karakter anak-anak. Program bertujuan meningkatkan mutu karakter anak-anak dan motivasi dalam belajar. Kegiatan program terbagi tiga tahap, yaitu persiapan, pelaksanaan, dan evaluasi. Metode pembelajaran menggunakan konsep belajar dan bermain. Bentuk pembelajaran berupa pemberian materi penanaman karakter, pemberian motivasi, bermain di lingkungan sekitar. Peserta program sebanyak 45 anak, terdiri dari anak prasekolah, usia SD, dan yang tidak bersekolah. Program berlangsung sebulan. Berdasarkan hasil dan evaluasi, program 'Teras Impian' berhasil meningkatkan sikap sopan santun anak terhadap orang tua, teman sebaya, kemampuan membaca iqra, serta kemampuan menghafal surat-surat pendek $\mathrm{Al}$-qur'an.

Tawhid Based Character Growth Through Teras Impian in Tajur Village

The Tauhid-Based Character Growth Program Through 'Teras Impian' in Tajur Village is motivated by the condition of the people of Kampung Parung Ponteng who do not pay much attention to children's character education. The program aims to improve the quality of children's character and motivation in learning. The program activities are divided into three stages, namely the preparation, implementation and evaluation. The learning method uses the concepts of learning and playing. Forms of learning include the provision of material for planting characters, giving motivation, playing in the surrounding environment. The program participants are 45 children, consisting of preschool, elementary school age, and those not in school. The program lasts for one month. Based on the results of the evaluation, the 'Teras Impian' program succeeded in increasing children's courtesy toward parents, peers, iqra reading skills, and the ability to memorize short Al-Qur'an surah.
\end{abstract}


Penumbuhan Karakter Berbasis Tauhid Melalui Teras Impian...

PENDAHULUAN

Penguatan spiritual dan keagamaan merupakan salah satu aspek yang terpenting dalam proses pendidikan. Dalam UU Nomor 20 Tahun 2003 tentang Sistem Pendidikan Nasional disebutkan bahwa pendidikan bertujuan mendidik manusia Indonesia agar beriman dan bertaqwa kepada Allah SWT, berperilaku mulia, sehat, berilmu, cakap, kreatif, dan mandiri. Oleh karena itu pendidikan terutama pendidikan moral dan karakter serta peningkatan kualitas akhlak yang baik menjadi hal yang mutlak untuk dilaksanakan.

Permasalahan moralitas di kalangan anak-anak atau usia remaja telah menyita perhatian dunia pendidikan. Sejumlah kasus seperti perundungan terjadi tidak saja di usia remaja (siswa SMP/SMA) tetapi juga terjadi pada usia anak sekolah dasar. Menurut KPAI, kasus perundungan di Indonesia menempati urutan kasus kekerasan pada anak (Hendrian, 2018). Pada tahun 2018, KPAI mencatat kasus perundungan paling banyak terjadi (Widiastuti, 2018). Sekitar 67\% kekerasan bidang pendidikan terjadi di tingkat SD (Maradewa, 2019).
Penumbuhan karakter berbasis tauhid melalui teras impian merupakan program bentuk aksi pendidikan dalam memperkuat karakter dan moralitas di kalangan anak-anak. Program berbentuk proses edukasi moral dan karakter serta pembiasaan praktik perbuatan baik. Program tersebut dirancang didasarkan kepada permasalahan kurangnya pendidikan karakter yang terjadi di Desa Tajur kampung Parung Ponteng khususnya RW 07. Berdasarkan observasi awal masyarakat Desa Tajur kampung Parung Ponteng dengan kondisi antara lain: 1) tidak adanya PAUD di Desa Tajur Khususnya Rw 07 kampung, sehingga tidak tersedianya sarana bermain dan belajar bagi anak usia 4-7 tahun atau prasekolah. Hal ini juga mengakibatkan kurangnya motivasi anak untuk menempuh jenjang sekolah dasar; 2) kurangnya pengawasan dan perhatian orang tua terhadap perkembangan anak yang berdampak pada rendahnya penanaman moral.

Karakter menggambarkan watak dan kepribadian seseorang, masyarakat, atau bangsa. Perbedaan karakter membedakan seseorang dengan orang lain. Karakter bangsa mencerminkan 
sifat-sifat kondisi kejiwaan dan kepribadian bangsa Indonesia (Bahasa, 2008; Bisri, 2017).

Karakter luhur bangsa merupakan watak bangsa Indonesia yang berperilaku selalu didasarkan pada kesadaran, mawas diri, dan pengendalian diri (Wagiran, 2012). Sifatsifat kondisi kejiwaan luhur bangsa menggambarkan kearifan lokal (local wisdom) masyarakat Indonesia seperti perasaan keagamaan yang kuat, jujur, toleran, kebersamaan, tanggung jawab, dll.

Pendidikan karakter penting dilakukan kepada anak-anak dalam membentuk watak dan kepribadian bangsa (Murniyetti, Engkizar, \& Anwar, 2016). Dalam konstelasi persaingan global, kekuatan bangsa tidak hanya bergantung pada penguasaan IPTEK semata tetapi juga pada kekokohan kepribadian sebagai fondasi dalam bersikap dan berperilaku.

Pendidikan karakter merupakan pendidikan budi pekerti plus yang mencakup dimensi teori pengetahuan, perasaan, dan tindakan (Muslich, 2011). Dimensi pendidikan karakter tersebut mengintegrasikan aspek kognitif, afektif, dan psikomotorik versi taksonomi Bloom sebagai ranah hasil belajar sekaligus memuat budi pekerti.

Pendidikan karakter berorientasi untuk membentuk kebiasaan (habit) perbuatan baik. Proses pembiasaan dilakukan sejak anak berusia dini sehingga sifat baik menjadi watak anak yang menetap. Anak yang terbiasa berbudi pekerti luhur dapat mengambil keputusan dengan baik dan bijak (Fitri, 2012).

Menurut Khan (2010) pendidikan karakter adalah serangkaian kegiatan yang diselenggarakan dengan segenap daya upaya, penuh kesadaran dan terprogram yang bertujuan untuk mengarahkan anak didik. Pendidikan karakter juga berupaya untuk meningkatkan kualitas pendidikan dan pengembangan budi, mengajarkan, membimbing, dan membina setiap manusia untuk memiliki kompetensi intelektual, karakter, dan keterampilan.

Nilai-nilai pendidikan karakter yang ditanamkan melalui proses pendidikan baik secara informal, formal maupun nonformal. Dimensi karakter dalam pendidikan formal dijabarkan kedalam 18 nilai yakni religius, jujur, toleran, disiplin, kerja keras, kreatif, mandiri, demokratis, rasa ingin tahu, 
Penumbuhan Karakter Berbasis Tauhid Melalui Teras Impian...

nasionalis, cinta tanah air, menghargai prestasi, bersahabat, cinta damai, gemar membaca, peduli sosial, peduli lingkungan, dan bertanggung jawab.

Pendidikan karakter dalam perspektif Frye, dkk. (2002) sebagai usaha yang disengaja untuk membantu orang memahami, peduli tentang sesuatu, dan bertindak atas dasar nilainilai etis. Pendidikan karakter tidak sekedar mengajarkan mana yang benar dan mana yang salah kepada anak, tetapi lebih dari itu pendidikan karakter menanamkan kebiasaan (habituation) tentang yang baik sehingga peserta didik paham, mampu merasakan, dan mau melakukan yang baik.

Dimensi pendidikan karakter dalam perspektif Frye mencakup tiga potensi anak yaitu: pikiran, rasa, dan raga (Yaumi, 2014). Potensi pikiran sebagai piranti untuk mengembangkan pengertian dan pemahaman anak tentang sesuatu sikap, perilaku, dan perbuatan. Potensi rasa berperan sebagai dasar anak dalam menilai sesuatu yang dilihat, dialami. Potensi raga merupakan wahana untuk mewujudkan pikiran dan rasa secara etis. Keterkaitan dimensi pikiran, rasa, dan raga dalam pendidikan karakter dapat digambarkan sebagai berikut:

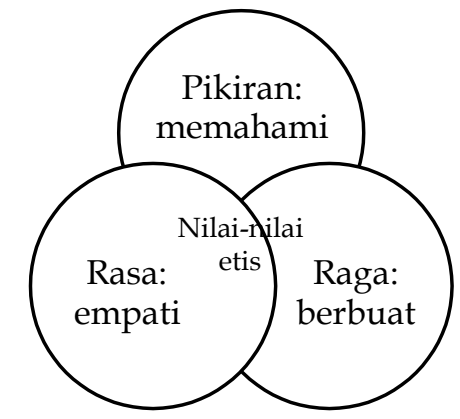

Gambar 1 Dimensi Pendidikan Karakter

Pendidikan karakter secara substantif membawa misi yang sama dengan pendidikan akhlak atau pendidikan moral. Akhlak secara terminologi berbeda dengan karakter. Secara etimologi, akhlak memiliki makna yang sama dengan budi pekerti. Dalam hal ini budi pekerti sebagai perpaduan antara rasio dan rasa yang terwujud dalam perilaku (Djatnita, 1992).

Konsep akhlak tidak terbatas pada dimensi hubungan perilaku manusia dengan manusia lain (Al-Syaibany, 1979). Dimensi akhlak mencakup perbuatan baik manusia yang berhubungan dengan Allah SWT (ibadah), hubungan antar sesama manusia (muamalah), dan hubungan manusia dengan alam sekitar.

Pendidikan karakter memiliki tiga fungsi utama untuk pengembangan 
potensi anak, memperbaiki dan memperkuat pranata sosial, dan nilainilai budaya bangsa (Zubaedi, 2011). Bagi anak, pendidikan karakter berfungsi untuk membentuk mengembangkan potensi yang dimilikinya. Anak melalui pendidikan karakter dibentuk agar memiliki pemikiran, hati nurani, dan perilaku yang luhur sesuai dengan nilai-nilai dan kepribadian bangsa. Kedua, pendidikan karakter berfungsi untuk memperbaiki dan memperkuat pranata sosial seperti keluarga, sekolah, masyarakat, dan pemerintah. Pranata sosial turut berpartisipasi dan bertanggung jawab mengembangkan potensi anak bangsa. Ketiga, pendidikan karakter berfungsi untuk menyaring budaya asing dan menjaga kelestarian nilai-nilai budaya dan kepribadian bangsa. Pendidikan memfilter budaya asing yang sesuai dan tidak sesuai dengan nilai watak, karakter, dan budaya bangsa Indonesia.

Berdasarkan uraian diatas disimpulkan bahwa pendidikan karakter adalah sebuah proses pembekalan yang melatih potensi anak secara sistematis dan berkesinambungan yang dipadukan dengan dasar-dasar keagamaan, kegiatan yang dilakukan ialah secara sadar dan sengaja untuk membentuk kebiasaan anak sejak dini agar kualitas anak dalam mengambil keputusan, berkomunikasi, peka terhadap lingkungan, bersikap terhadap antarmakhluk-Nya menjadi bijaksana dan jauh lebih baik lagi sehingga menghasilkan generasi muda yang cerdas, jujur, santun, dermawan, dan religius. Nilai-nilai karakter demikian yang mendorong tim untuk melaksanakan program pengabdian kepada masyarakat untuk menumbuhkan karakter berbasis tauhid.

\section{METODE}

Program penumbuhan karakter berbasis tauhid melalui teras impian dilaksanakan di kampung Parung Ponteng Desa Tajur, Citereup.

Program penumbuhan karakter berbasis tauhid melalui 'Teras Impian' dilakukan dalam tiga tahap: 1) persiapan, 2) pelaksanaan, dan 3) evaluasi.

\section{- Persiapan Program}

Pada tahap persiapan program dilakukan observasi lapangan untuk memetakan persoalan sosial dan kebutuhan masyarakat. Setelah 
persoalan dipetakan kemudian disusun program aksi sesuai kebutuhan masyarakat. Cakupan kegiatan 'Teras Impian' terdiri dari proses pembelajaran dan bermain. Materi kegiatan disusun dengan orientasi pengembangan potensi dan pendidikan karakter anak.

\section{- Pelaksanaan Program}

Dalam tahap pelaksanaan, program diikuti oleh anak-anak dengan usia masih di bawah 7 tahun, anak-anak tingkat SD yang sebagian besar dari SDN Tajur 07, serta anak-anak yang tidak bersekolah.

Kegiatan 'Teras Impian' menargetkan minimal 60\% mutu akhlak anak meningkat. Hal itu diasumsikan bahwa akhlak dalam kehidupan seharihari seperti tata krama, sopan santun, tata bahasa sangat penting untuk dapat membaur dan hidup di masyarakat.

Titik berat kegiatan pembelajaran yakni meningkatkan motivasi belajar, perubahan sifat, kebiasaan anak untuk berkomunikasi dengan bahasa yang baik dan sopan terhadap orang yang lebih tua, sesama, maupun orang yang lebih muda dari mereka. Di samping itu, kegiatan 'Teras Impian" menekankan peningkatan kemampuan verbal seperti membaca iqra, hafalan surat pendek Alqur'an juz 30. Pelaksanaan pembelajaran melibatkan mahasiswa dengan jadwal mengajar bergilir. Para mahasiswa sebanyak tiga sampai empat orang setiap di sore dan malam hari setelah maghrib membawakan materi dalam kegiatan pengajian anak-anak.

Pemberian motivasi belajar dilakukan untuk mendorong anak-anak agar memiliki kemauan belajar, mengejar impian dan cita-cita setinggi mungkin. Kegiatan pemberian motivasi menggunakan media 'Galaksi Impian'. Media ini merupakan media dari papan yang didekorasi menyerupai galaksi dengan semenarik mungkin untuk menggantungkan cita-cita anak yang mereka tulis di sebuah kartu bertali. Papan Galaksi Impian dibuat dengan tujuan memotivasi anak dalam meraih cita-citanya. Kartu bertali juga berisi bagaimana upaya yang harus dilakukan anak agar setiap cita-cita yang sudah mereka gantungkan tersebut menjadi kenyataan. 


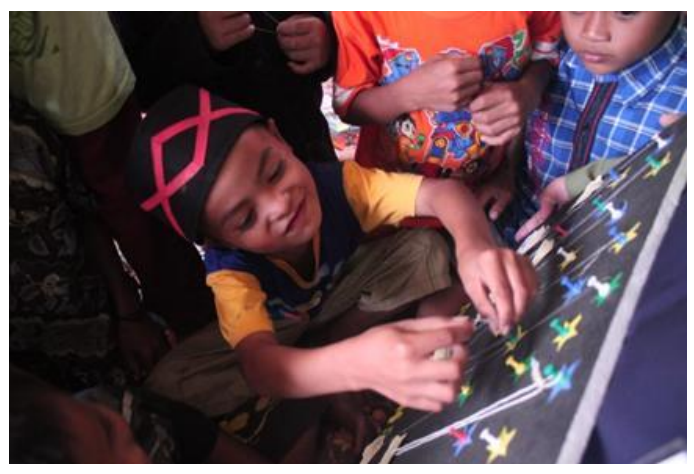

Gambar 2 Anak menggantungkan kartu bertali di papan Galaksi Impian

\section{- Evaluasi Program}

Tahap terakhir ialah melakukan evaluasi. Bentuk evaluasi dilakukan dengan cara wawancara dan observasi. Wawancara secara langsung kepada anak-anak untuk mengetahui tanggapan terhadap program. Observasi bertujuan untuk mengetahui tingkat perkembangan peningkatan pendidikan karakter dan moral anak setelah program teras impian dilaksanakan dalam kurun waktu satu bulan.

Data yang diperoleh antara lain berupa jumlah anak yang telah mampu membaca iqra, jumlah anak yang telah mampu menghafal minimal 10 surat pendek Al-qur'an di juz 30. Capaian dari aspek karakter di antaranya meningkatnya perilaku dan kebiasaan anak untuk menjadi lebih sopan dan santun.

\section{HASIL \& PEMBAHASAN}

Program diawali dengan kegiatan pengamatan/observasi terlebih dahulu di lokasi pengabdian masyarakat. Tujuan observasi yaitu: 1) untuk mengetahui bentuk penanaman akhlak, perilaku dan kebiasaan sopan santun, 2) kemampuan anak dalam membaca iqra dan kemampuan anak menghafal surat pendek Al-qur'an juz 30 di Desa Tajur khususnya Kampung Parung Ponteng RW 07. Setelah proses pengamatan dilaksanakan kemudian merancang melaksanakan program Teras Impian.

Kegiatan pembelajaran bertujuan untuk meningkatkan pendidikan karakter. Kegiatan 'Teras Impian' mengintegrasikan proses belajar dan bermain. Waktu pembelajaran berlangsung pada sore hari yakni pada hari Senin, Rabu dan Jum'at. Durasi kegiatan selama satu bulan.

Pembelajaran yang dilaksanakan sore hari terbagi kedalam beberapa bagian. Pertama pembelajaran dengan pemberian materi kepada anak. Materi yang diberikan berupa kisah-kisah nabi, kisah-kisah yang memuat isi atau pesan yang baik, dan pemberian pengetahuan akhlak baik dan akhlak buruk terhadap teman sebaya dan sopan santun 
Penumbuhan Karakter Berbasis Tauhid Melalui Teras Impian...

terhadap orang tua. Penyampaian kisah-kisah tersebut dikemas secara menarik menggunakan teknik dongeng, menggunakan media wayang dan boneka. Selain itu agar pembelajaran menarik tempat belajar di dekorasi dengan memanfaatkan barang yang terbuat dari sampah anorganik yang telah dipilih oleh masyarakat. Metode mengajar lain yang diterapkan dengan menggunakan metode picture and picture.

Kedua pembelajaran dengan tujuan melatih kreativitas anak.

Bentuk kegiatan pembelajaran seperti menggambar dan mewarnai, belajar kaligrafi dengan menulis tulisan Arab, bernyanyi "aqoidul iman". Anak-anak setelah bernyanyi diberikan pemahaman tentang pentingnya mengimani sifat-sifat yang hak dan bathil pada Allah dan Rasul-Nya serta bagaimana mengimplementasikan aqoidul iman dalam kehidupan seharihari.

Ketiga pembelajaran dengan membawa anak ke alam bebas dan memberikan mereka kesempatan untuk mengeksplorasi rasa ingin tahu berdasarkan apa yang mereka lihat dan rasakan. Anak-anak diajak berinteraksi secara langsung dengan masyarakat. Pembelajaran ini dinilai sangat efektif karena melibatkan anak secara langsung dalam proses belajarnya. Anak-anak dengan melihat dan merasakan secara langsung menurut teori konstruktivis pengetahuan mereka akan secara langsung masuk kedalam memori anak sebagai sebuah pengalaman yang akan menempel dalam ingatannya dengan akurat (Alzahrani \& Woollard, 2013; Zhang, 2019).

\section{- Pengetahuan Religius}

Pembelajaran dalam rangka meningkatan pengetahuan religius anak-anak dilaksanakan waktu malam tiap hari. Pembelajaran ini dilaksanakan dalam tiga bagian. Pertama, pembelajaran yang dilaksanakan dengan tujuan meningkatkan kemampuan membaca anak terhadap huruf hijaiyyah dan iqra. Pembelajaran ini diberikan dengan bantuan dan bimbingan mahasiswa dalam mengeja dan membaca iqra. Kedua, pembelajaran yang bertujuan meningkatkan kemampuan menghafal surat pendek Al-qur'an juz 30. 


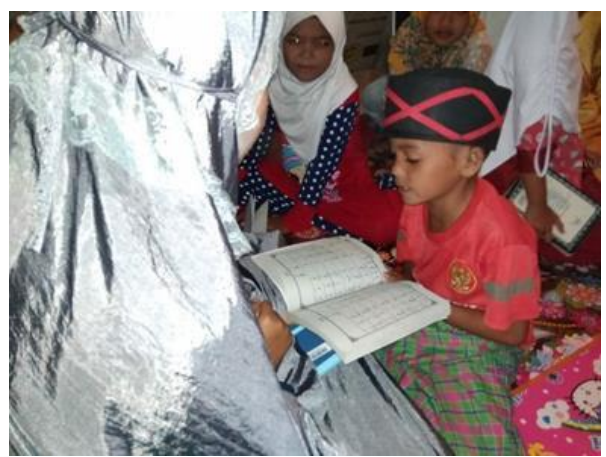

Gambar 3 Hapalan Surat-Surat Pendek Juz 30

Pembelajaran ini dilaksanakan dengan berbagai metode pendukung guna memudahkan pencapaian hafalan yang diprogramkan. Metode klasik, yakni pemberian bacaan yang kemudian anak dibimbing untuk menghafal. Metode rombel atau rubik surat, yakni mengacak urutan ayat pada sebuah surat dan anak diminta untuk menyusun ayat tersebut menjadi satu surat yang utuh. Metode ini dianggap cukup berhasil memberikan pengaruh kecepatan dan melekatnya ingatan hafalan karena membaca ayat dengan berulang kali. Metode selanjutnya adalah sambung ayat, metode ini melatih kemampuan anak dalam cepat tanggapnya anak. Metode terakhir adalah dengan menggunakannya reward atau penghargaan kepada anak. Pemberian reward ini adalah sebagai upaya meningkatkan motivasi anak dalam menghafal, karena dengan adanya pemberian reward anak lebih antusias dan lebih bersemangat dikarenakan adanya motivasi yang berupa bonus hasil jerih payah menghafalnya secara langsung. Reward yang diberikan beragam, seperti alat tulis, makanan ringan, coklat. Reward yang diberikan pun tidak hanya berupa hadiah berbentuk fisik, melainkan hadiah yang tidak nampak atau berbentuk pujian yang dapat meningkatkan motivasi dan semangat moral anak. Metode ini dinilai sangat efektif untuk meningkatkan motivasi anak dalam menghafal sehingga memaksimalkan strategi pembelajaran menghafal surat pendek Al-qur'an juz 30.

\section{- Sopan Santun Terhadap Orang Tua}

Proses penanaman perilaku sopan santun terhadap orang tua dilaksanakan dalam setiap kegiatan. Di antaranya, kegiatan bermain dan belajar yang dilaksanakan sore hari maupun kegiatan peningkatan pemahaman religius pada malam hari.

Berdasarkan hasil observasi awal diketahui bahwa sebesar $13 \%$ atau dapat dikatakan sebanyak 6 orang yang dikategorikan telah mampu bersikap baik dan sopan kepada orang tuanya dari jumlah 45 anak. Kurangnya sikap 
Penumbuhan Karakter Berbasis Tauhid Melalui Teras Impian...

dan perilaku sopan santun anak terutama adab terhadap orang tua, teman sebaya, dan orang di sekitarnya. Di samping itu anak-anak terbiasa menggunakan bahasa kasar dan tidak mendidik. Keadaan tersebut merupakan permasalahan yang membutuhkan penanganan. Untuk itulah program penumbuhan karakter disusun guna menangani masalah tersebut.

Pembelajaran dilaksanakan dengan berbagai teknik dan pendekatan, seperti pendekatan persuasif baik secara verbal maupun nonverbal. Pembelajaran dilaksanakan di dalam kegiatan maupun di luar kegiatan. Pembelajaran yang dilaksanakan di dalam seperti pemberian materi dongeng. Dalam materi dongeng memuat kisah yang memberikan amanat pentingnya menjaga sopan santun terhadap orang tua. Dongeng disajikan semenarik mungkin dengan bantuan dekorasi dan intonasi yang sesuai sehingga menciptakan suasana yang aktif, menyenangkan dan efektif. Sedangkan pembelajaran di luar dengan cara memberikan pemahaman saat anak berkunjung ke posko, memberikan arahan secara langsung tentang perlunya menjaga adab terhadap orang tua, dan bermain bersama.

Setelah anak-anak mengikuti pembelajaran selama satu bulan berdasarkan hasil evaluasi akhir, mereka mengalami perubahan perilaku yang lebih baik. Sebagian besar anak mampu bersikap baik dan sopan kepada orang tuanya, sekalipun dalam rentang penilaian baik dalam bersikap sopan kepada orang tuanya bervariasi. Perubahan perilaku dapat dilihat dari meningkatnya cara berbicara anak kepada orang tuanya yang lebih sopan dan sudah tidak membentak serta tidak memakai nada tinggi. Selain itu, anakanak tidak menggunakan kata-kata yang kasar dalam kehidupan sehari-hari terutama kepada orang tuanya, anak sudah dapat memilih kata yang tepat kepada orang tuanya. Secara keseluruhan anak telah menunjukkan peningkatan perubahan perilaku yang lebih baik secara signifikan.

\section{Adab Terhadap Teman Sebaya}

Penanaman kebiasaan beradab terhadap teman sebaya selalu dilakukan dalam setiap pelaksanaan kegiatan ‘Teras Impian'. Sama halnya dengan penanaman sifat sopan santun dan tata krama terhadap orang tua, 
pembelajaran adab terhadap teman sebaya pun dilaksanakan pada sore dan malam hari.

Berdasarkan hasil observasi awal diketahui bahwa sekitar $11 \%$ atau sebanyak 5 orang yang sudah mampu untuk dikategorikan baik dalam beradab dengan teman sebayanya dari jumlah total 45 anak. Hal ini dilihat pada saat proses interaksi anak bersama teman. Pergaulan anak di lokasi pengabdian umumnya tidak terawasi dengan baik oleh orang tuanya. Beberapa orang tua bahkan membiarkan dan tidak terlalu memperhatikan pergaulan anakanaknya sehingga menyebabkan perilaku anak cenderung tidak terkontrol baik kepada orang tua maupun sesama teman sebaya.

Proses pelaksanaan pemberian materi pembelajaran untuk menanamkan sopan santun pada teman sebaya dengan cara pemberian materi pada saat pengajian dan pembelajaran di Teras Impian. Selain itu, penanaman sikap sopan santun pada teman sebaya dengan memberikan teguran. Bentuk teguran diberikan pada saat anak menggunakan kata yang tidak baik bahkan cenderung kasar ketika mereka bermain dan bercengkrama dengan teman sebayanya. Pemberian teguran dilakukan dengan spontan atau secara langsung. Anak yang berkata tidak sopan atau kasar diberikan nasihat, serta masukan agar menggunakan bahasa yang santun dan lebih baik. Anak juga mendapat penjelasan tentang dampak dari penggunaan kata yang tidak baik ketika berbicara kepada teman yang lain. Pengajaran spontan dan secara langsung dianggap lebih efektif karena lebih tepat sasaran dan dapat diterima langsung oleh anak.

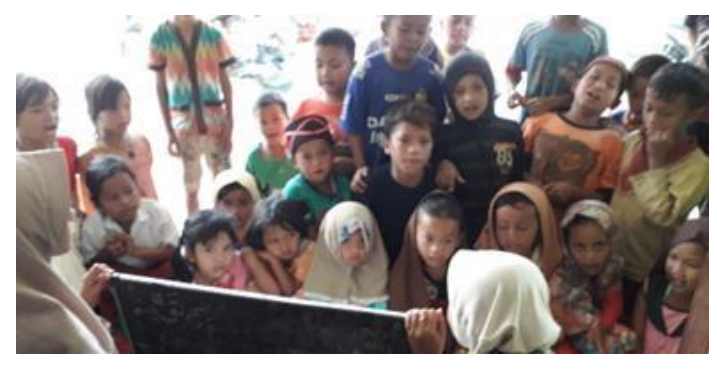

Gambar 4 Bentuk Kegiatan Pembelajaran

Pemberian pengajaran tentang materi ini juga dilaksanakan dengan pemberian pemahaman dengan cara materi disertai dengan metode make a match yakni mencocokkan gambar adab yang baik terhadap teman sebaya sesuai dengan pengertiannya.

Setelah dilaksanakan proses pengamatan, dilanjutkan dengan memberikan proses pembelajaran yang memuat konten penyadaran anak 
Penumbuhan Karakter Berbasis Tauhid Melalui Teras Impian...

terhadap pentingnya menjaga dan menerapkan adab terhadap teman sebaya sehingga pada tahap evaluasi terjadi peningkatan jumlah anak yang telah mampu menerapkan adab yang baik terhadap teman sebayanya menjadi sebesar $75 \%$ atau sebanyak 34 dari 45 anak sudah mampu mengaplikasikan sopan santun, bertutur kata yang baik, dan bertata krama dengan teman sebaya.

Peningkatan signifikan tersebut dapat dilihat dari proses interaksi sesama teman sebayanya yang sudah mampu dijaga sehingga tidak menggunakan bahasa yang kasar dan kurang baik. Selain itu, proses interaksi yang dilakukan terlihat sudah tidak adanya tindakan perundungan (bullying), karena perlu diketahui tujuan peningkatan adab terhadap teman sebaya ini ialah untuk membrantas adanya tindakan perundungan yang terjadi pada beberapa anak yang dianggap lemah oleh anak yang lebih mendapat kedudukan tinggi bahkan cenderung "ditakuti" di antara temantemannya.

Berdasarkan hasil pengamatan tersebut, program 'Teras Impian' memberikan dampak positif terhadap perilaku dan karakter anak terutama dalam pergaulan sesama teman sebaya di Desa Tajur.

\section{- Kemampuan Membaca Iqra}

Berdasarkan pengamatan awal diketahui sekitar $22 \%$ atau 10 anak yang sudah mampu membaca iqro dengan baik dan benar dari jumlah 45 anak, sisanya dapat dikategorikan tidak bisa membaca huruf hijaiyyah sama sekali. Dalam pelaksanaan program ini anak diberikan bimbingan membaca iqra setiap hari setelah maghrib yang dilakukan selama satu bulan. Selain pemberian membaca iqra, anak juga dilatih keterampilan mewarnai huruf hijaiyyah. Kegiatan ini berdampak pada peningkatan motorik kasar dan motorik halus serta motivasi anak terhadap membaca iqra.

Setelah diberikannya pengajaran, berdasarkan hasil evaluasi diperoleh adanya peningkatan jumlah anak yang mampu membaca. Hampir seluruh anak atau sekitar 91\% dari 45 anak sudah mampu membaca iqra dengan baik. Rentang kemampuan anak membaca iqra dengan kategori baik berbeda, seperti kemampuan anak yang baru bisa mengeja, sampai ke tahap yang sudah lancar membaca iqra. 
Berdasarkan data tersebut, program Teras Impian berkontribusi terhadap peningkatan kemampuan membaca iqra di kalangan anak di Desa Tajur.

\section{- Menghafal 10 Surat Pendek Al- qur'an Juz 30}

Kemampuan anak-anak di kampung Parung Ponteng berdasarkan pengamatan awal tergolong masih rendah. Ada sebesar $20 \%$ atau 9 dari 45 anak sudah mampu menghafal 10 surat pendek Al-qur'an juz 30. Anak ada yang sudah hafal 3-10 surat pendek dan ada anak yang belum hapal surat Al-fatihah. Tahap pembelajaran dilaksanakan setiap hari setelah maghrib setelah bimbingan membaca iqra. Proses hafalan yang ditugaskan disesuaikan dengan kemampuan masing-masing anak. Proses diberikannya reward menjadikan keuntungan tersendiri bagi pemateri karena dapat lebih memotivasi anak dalam menghafal.

Pada tahap evaluasi dilaksanakan, jumlah anak yang dapat menghapal meningkat. Sekitar $86 \%$ atau 39 anak dari keseluruhan jumlah anak yang ikut kegiatan di 'Teras Impian' sudah dapat menghafal 10 surat pendek Al-qur'an juz 30. Tingkat keberhasilan ini bervariasi, ada anak yang sudah dapat menghafal 10 surat pendek bahkan ada beberapa anak hafal lebih dari 10 surat. Sebagai contoh, Gozali yang sudah mendapatkan motivasi menghapal Alqur'an dari arahan orang tuanya, kini setelah mendapatkan pembelajaran menghafal dalam program 'Teras Impian' ia sudah mampu menghafal sekitar 25 surat pendek. Hal ini menjadi kebanggaan tersendiri, karena dibawah lingkungan yang memang tidak mendukung namun masih ada saja yang masih bertahan untuk tetap menghafal dan bercita-cita menjadi seorang ulama.

Pencapaian program penumbuhan karakter berbasis tauhid melalui 'Teras Impian' di Desa Tajur berdampak positif dalam mewujudkan tujuan Pendidikan karakter anak-anak.

Pendidikan karakter bertujuan untuk membentuk pribadi anak menjadi manusia yang lebih baik bagi diri, keluarga, masyarakat, dan negara. Hasil dari pendidikan yang diharapkan tidak hanya menjadi manusia yang cerdas, namun yang memiliki karakter baik secara emosional dan spiritual. Fokus pendidikan karakter adalah perubahan perilaku dalam bentuk perilaku yang baik kepada sesama. Mutu pendidikan karakter pada 
Penumbuhan Karakter Berbasis Tauhid Melalui Teras Impian...

akhirnya dilihat pada kualitas manusia yang dihasilkan. Pada konteks hasil program 'Teras Impian” telah dihasilkan mutu anak-anak yang lebih santun dalam berkata, berperilaku baik kepada orang tua serta teman sebaya.

Lingkungan dalam bentuk 'Teras Impian' yang dihadirkan di tengah anak-anak kampung Parung Ponteng berperan sebagai faktor eksternal yang berpengaruh dalam pembentukan karakter anak. Tersedianya lingkungan yang baik sangat penting untuk tumbuh dan berkembangnya karakter anak sejak dini.

Peran lingkungan dalam membangun karakter anak dijelaskan Fadilah(2016). Menurutnya, keliru jika dalam membentuk karakter anak hanya mendasarkan pada "kehendak dan cita idiilnya", tetapi menafikan faktor lingkungan belajarnya (fisik dan nonfisik). Kekeliruannya, karena kita melupakan pola dan iklim kehidupan nyata anak dalam kehidupannya di sekolah dan atau bersama temannya. Padahal lingkungan tersebut amat menentukan terhadap pembentukan diri anak, karena melalui lingkungan tersebut, anak menyerap nilai dan keyakinan yang dikehendaki masyarakat serta digunakan sebagai kekuatan moral dalam hidupnya.

Dari pembahasan di atas dapat dilihat bahwa usaha yang dilakukan untuk meningkatkan mutu pendidikan karakter di Kampung Parung Ponteng khususnya RW 07, Desa Tajur berdampak positif dalam penumbuhan dan penanaman karakter anak. Program berkontribusi dalam mengubah sikap dan perilaku anak menjadi lebih baik, menjaga tata krama, budi pekerti ketika berbicara kepada orang tua dan teman. Pendidikan karakter yang dicanangkan dalam program Teras Impian tidak hanya berorientasi pada pengembangan aspek kognitif dan pengetahuan saja, melainkan juga pembiasaan perbuatan yang baik, perasaan spiritual yang diaplikasikan dalam kehidupan sehariharinya.

\section{SIMPULAN}

Berdasarkan hasil evaluasi pada peserta program, dapat diketahui bahwa program Teras Impian yang berlangsung selama satu bulan telah berhasil meningkatkan sikap sopan dan santun anak terhadap orang tua, adab terhadap teman sebaya, kemampuan membaca iqra, dan menghafal 10 surat pendek Al-qur'an juz 30. Tingkat 
keberhasilan program dengan rata-rata mencapai $88 \%$ dari target pencapaian $60 \%$ keberhasilan.

Hasil program secara kualitatif berupa perilaku/karakter anak yang diwujudkan dalam kehidupan seharihari baik berhubungan dengan orang tua maupun teman sebaya. Berikut deskripsi hasil program secara kualitatif.

- Peningkatan Sopan Santun Anak Kepada Orang Tua

Perubahan ini dapat dilihat dari sudah mampunyai anak memilah dan memilih kata yang lebih pantas dan sopan untuk digunakan dalam berkomunikasi kepada orang tua. Selain itu, anak sudah tidak lagi membentak kepada orang tua dan menggunakan nada tinggi dalam kehidupan seharihari, dimana hal tersebut kami dapatkan dengan melakukan wawancara kepada para orang tua anak peserta program Teras Impian.

- Adab Anak Terhadap Teman Sebaya

Program ini telah mampu meningkatkan adab terhadap teman sebayanya dengan tidak adanya lagi tindakan perundungan dan interaksi dengan menggunakan bahasa yang kasar serta rasa saling peduli antar sesama teman.

- Kemampuan Anak Membaca Iqra

Terlihat dari meningkatnya angka anak yang sudah mampu membaca iqra dan lebih termotivasi untuk mengaji di setiap hari.

- Kemampuan Anak Menghafal Surat

Pendek Al-qur'an

Program ini membuat anak-anak semakin termotivasi untuk menghafal surat-surat pendek di dalam Al-qur'an dan menambah bekal pada anak-anak sebagai bacaan surat yang dibaca ketika shalat lima waktu.

Ketercapaian program tersebut mengindikasikan bahwa program ini berhasil memotivasi anak-anak agar berusaha mencapai kehidupan yang lebih baik. Pendidikan bukan hanya sebagai proses untuk memperoleh pengetahuan (knowledge), tetapi juga bagaimana pengetahuan dapat diaplikasikan dengan baik dan benar di kehidupan bermasyarakat berdasarkan nilai-nilai yang menjadi dasar keyakinan dan kepribadian masyarakat

\section{IMPLIKASI}

Program Teras Impian diharapkan dapat terus di laksanakan bersamaan dengan program desa yang 
Penumbuhan Karakter Berbasis Tauhid Melalui Teras Impian...

berkesinambungan terkait pendidikan yang ada di Desa Tajur khususnya di kampung Parung Ponteng.

'Teras Impian' memusatkan pada pendidikan karakter anak sehingga bersinergi dengan program pemerintah dalam pembangunan karakter bangsa. Program juga akan berlangsung secara kontinu jika terintegrasi dengan kegiatan pendidikan sekolah regular pada jenjang pendidikan dasar maupun menengah.

'Teras Impian' tidak hanya menekankan aspek afektif semata, tetapi ia menjadi wadah sekaligus dalam mengembangkan aspek psikomotorik, mengasah keterampilan dan kreatifitas. Anak dilatih membuat sesuatu ataupun mengolah benda apapun yang kurang memiliki nilai diubah menjadi kerajinan yang memiliki nilai berbeda dan lebih baik. Kemampuan psikomotorik anak pun dapat terarah dan berkembang.

'Teras Impian' akan dapat berperan lebih baik jika mendapat dukungan dari pemerintah setempat. Pendidikan di kampung Parung Ponteng dapat berkembang jika sumber daya manusia setempat dapat mengembangkan nilainilai kearifan lokal sebagai kekayaan bangsa Indonesia. Persaingan global tidak hanya membutuhkan kecerdasan akan tetapi juga perlu memiliki skill dan sikap positi atau nilai-nilai yang mencerminkan moralitas bangsa. 'Teras Impian' yang dirintis di Kampung Parung Ponteng menjadi wadah anak mengembangkan diri secara secara komprehensif.

\section{UCAPAN TERIMA KASIH}

Ucapkan terima kasih kami sampaikan sebesar-besarnya kepada BAPPEDA (Badan Perencanaan Pembangunan Daerah), Universitas Djuanda Bogor, Kepala Desa Tajur beserta staf yang telah membantu pelaksanaan program, Ketua RW 07, RT 01 dan RT 02, Kepala SDN Tajur 07 dan seluruh masyarakat setempat yang telah ikut serta menyukseskan kegiatan pengabdian kepada masyarakat berupa program 'Teras Impian'.

\section{DAFTAR PUSTAKA}

Al-Syaibany, O. M. A.-T. (1979). Falsafah Pendidikan Islam (I). Jakarta: Bulan Bintang.

Alzahrani, I., \& Woollard, J. (2013). The Role of the Constructivist Learning Theory and Collaborative Learning Environment on Wiki Classroom, and the Relationship between Them. In 3rd International Conference For e-learning \& Distance Education. Riyadh: eLi.

Bahasa, P. (2008). Kamus Besar Bahasa 
Indonesia Pusat Bahasa (IV). Jakarta: PT Gramedia Pustaka Utama.

Bisri, H. (2017). Penilaian Otentik: Praktis dan Mudah Menarapkan (I). Bogor: UNIDA PRESS.

Djatnita, R. (1992). Sistem Etika Islami (Akhlak Mulia). Jakarta: Pustaka Panjimas.

Fadillah. (2016). Membangun Karakter Bangsa. In Sarbaini (Ed.), Membangun Karakter Kemanusiaan, Membentuk Kepribadian Bangsa Melalui Pendidikan (I, pp. 17-40). Banjarmasin: UPT MKU Universitas Lambung Mangkurat. https://doi.org/10.1017/CBO9781 107415324.004

Fitri, A. Z. (2012). Holistika Pemikiran

Pendidikan: Upaya Membangun

Manusia Berkarakter. In J. Musfah (Ed.), Pendidikan Holistik:

Pendekatan Lintas Perspektif (I, pp. 35-57). Jakarta: Kencana Prenada Media Group.

Frye, M., Lee, A. R., LeeGate, H., Mitchell, M., Turner, G., \& Vincent, V. F. (2002). Character Education Informational Handbook and Guide for Support and Implementation of the Student Citizen Act of 2001. North Carolina: Public School of North Carolina.

Hendrian, D. (2018). KPAI:

Perundungan Urutan Keempat Kasus Kekerasan Anak. Retrieved from

https://www.kpai.go.id/berita/k pai-perundungan-urutan-keempatkasus-kekerasan-anak

Maradewa, R. (2019). KPAI: 67 Persen

Kekerasan Bidang Pendidikan Terjadi di Jenjang SD.

Murniyetti, M., Engkizar, E., \& Anwar, F. (2016). Pola Pelaksanaan Pendidikan Karakter Terhadap Siswa Sekolah Dasar. Jurnal
Pendidikan Karakter, VI(2), 156-166. https://doi.org/10.21831/jpk.v6i2. 12045

Muslich, M. (2011). Pendidikan Karakter: Menjawab Tantangan Krisis Multidimensional. Jakarta: Bumi Aksara. Retrieved from https://books.google.co.id/books? $\mathrm{id}=$ o_uRpwAACAAJ

Wagiran. (2012). Pengembangan Karakter Berbasis Kearifan Lokal Hamemayu Hayuning Bawana. Jurnal Pendidikan Karakter, 2(3), 329-339.

Widiastuti, R. (2018). Hari Anak Nasional, KPAI Catat Kasus Bullying Paling Banyak. Tempo. Yahya, K. (2010). Pendidikan Karakter Berbasis Potensi Diri. Pelangi Publishing. Yogyakarta: Pelangi Publishing.

Yaumi, M. (2014). PENDIDIKAN KARAKTER: Landasan, Pilar, dan Implikasi (I). Jakarta: Kencana.

Zhang, X. (2019). An Empirical Approach and Implications for Teachers to Begin Constructivist Teaching. Open Journal of Social Sciences, 07(10), 375-386. https://doi.org/10.4236/jss.2019.7 10032

Zubaedi. (2011). Desain Pendidikan Karakter: Konsepsi dan Aplikasinya dalam Lembaga Pendidikan (I). Jakarta: Kencana.assessments based on learning trajectory for elementary school. Research and Evaluation in Education, 2(1), 13-24. doi: 10.21831/reid.v2i1.6540.

Svinicki, M. D. (2004). Authentic assessment: Testing in reality. New Directions for Teaching and Learning, 100(Winter 2004), 23-29. doi: 10.1002/tl.167.

Tombari, M.L \& Borich, G.D. (1999). Authentic Assessment in the classroom 
Penumbuhan Karakter Berbasis Tauhid Melalui Teras Impian...

(application and practice). Upper

Saddle River, NJ: Prentice Hall.

$\mathrm{Vu}, \mathrm{T}$. T., \& Alba, G. D. (2014).

Authentic assessment for student

learning: An ontological

conceptualisation. Educational

Philosophy and Theory, 46(7), 778-

791.

doi:10.1080/00131857.2013.795110.

Whitelock, D., \& Cross, S. (2012).

Authentic assessment: What does it mean and how is it instantiated by a group of distance learning academics? International Journal of e-Assessment, 2(1), article 9. Retrieved from http://journals.sfu.ca/ijea/index.p $\mathrm{hp} /$ journal/ article/view/31.

Wiggins, G. (1998). Educative assessment:

Designing assessments to inform and improve student performance. San Francisco, CA: Jossey-Bass. 